\title{
PLAY THERAPY ART EXPRESSION TEKNIK MENGGAMBAR UNTUK MENGURANGI STRES PESERTA DIDIK DALAM MENGERJAKAN TUGAS PEMBELAJARAN DARING
}

\author{
Etik Sulistyowati, S.Pd \\ SMK Negeri 1 Jetis Mojokerto / e-mail: etik.sulis@gmail.com \\ Anita Dianasari, S.Pd \\ SMK Negeri 1 Kemlagi Mojokerto / e-mail: anitadianasari@gmail.com
}

\begin{abstract}
Abstrak
Masa Pandemi Covid-19 merupakan masa tersulit bagi peserta didik. Salah satunya dampak terberat pada peserta didik yakni tekanan pembelajaran jarak jauh system dalam jaringan, yang mana interksi peserta didik dengan guru terbatas tidak selonggar ketika pembelajaran tatap muka di kelas. Secara psikologis anak ketika penerapaan pembelajaran jarak jauh yaitu tekanan dari orang tua maupun lingkungan sekitar dengan kompleksitas permasalahan yang ada, seringkali tidak dapat dihindari stress yang dialami oleh peserta didik, dalam hal ini stress akibat beban tugas pembelajaran jarak jauh atau daring. Artikel ini ditulis sebagai salah satu upaya untuk membantu memberikan solusi strategi untuk meringankan beban peserta didik tersebut. Play therapy art expression media menggambar dengan lima $\mathrm{R}$ tahap terapi ini yakni : Relating (Berhubungan), Releasing (Melegakan) perasaan, Re-Creating (menciptakan kembali), Reexperience (Mengalami kembali), dan Resolving (Memecahkan) harapannya dapat digunakan guru bimbingan konseling sebagai salah satu intervensi dalam membantu mengurangi stress pada peserta didik.ketika mendapat tekanan maupun beban berat dalam mengerjakan tugas pembelajaran daring
\end{abstract}

Kata kunci: pandemi Covid-19, play therapy art expression media menggambar, stress,

\begin{abstract}
The Covid-19 Pandemic period was the most difficult time for students. One of the heaviest impacts on students is the pressure of distance learning systems in the network, which between students and limited teachers is not as loose as face-to-face learning in class. Psychologically, the child when the application of distance learning is pressure from parents or the surrounding environment with the complexity of the existing problems, including being unable to avoid stress that can be avoided by students, in terms of stress due to distance learning or courageous tasks. This article was written as an effort to help provide strategic solutions to ease the burden on these students. The expression media of art therapy playing drawing with the five R stages of this therapy, namely: Relating (Relating), Releasing (Relieving) feelings, Re-creating (re-creating), Reexperiencing (Re-experiencing), and completing (Solving) hope that the counseling guidance teacher can use as one of the interventions to help reduce stress on students. When under pressure or burden in doing bold learning tasks
\end{abstract}

Keywords: Covid-19 pandemic, the media to draw the art expression of play therapy, stress,

\section{PENDAHULUAN}

Pandemi Covid -19 merambah ke seluruh negeri ini membawa dampak yang luar biasa kepada masyarakat Indonesia khususnya pada dunia pendidikan. Semua elemen pendidikan dari kementrian pendidikan, dinas pendidikan, guru tenaga pendidik dan kependidikan, peserta didik bahkan orang tua semuanya mengalami perubahan tatanan pendidikan selama masa pandei Covid-19. Bahkan peserta didik secara tidak langsung merasakan dampak resesi ekonomi dalam masa pandemic Covid-19. Ketika sebelum sebelum datang Covid-19 orang tua mereka berdagang dengan nyaman dan dapat pemasukan yang stabil, ketika orang tuanya bekerja di pabrik dengan gaji yang bisa diharapkan namun ketika pandemic Covid-19 datang suasana itu berubah drastis, banyak pedagang sepi karena terbatasnya pembeli dan ketakutan membeli di luar yang bedampak pada pemasukan pedagang, buruh pabrik yang banyak di PHK disebabkan kondisi perekonomian yang tidak stabil, semua kondisi ini berdampak pada situasi di dalam keluarga dan pada kondisi mental anak.

Ketika sebelum pandemi Covid-19 peserta didik bisa leluasa menggunakan fasilitas wifi di sekolahannya, namun ketika masa pandemi Covid19 mau tidak mau mereka harus membeli paket internet untuk bisa mengakses dari rumah. Guru 
tenaga pendidik pun merasakan dampak hal tersebut. Walaupun banyak aplikasi yang mendukung untuk pembelajaran jarak jauh bisa menggunakan goggle classroom, whtasapp group, zoom dll. Tetap saja keleluasaannya berbeda dengan pembelajaran tata muka, belum lagi kondisi daerah yang jaringannya internetnya belum stabil atau di daerah pegunungan maupun daerah pedesaan pedalaman semua itu merupakan kondisi nyata dan baru muncul persoalan baru ketika pandemic Covid19 ini datang. Tidak menutup kemungkinan suasana baru berdampak pada perilaku peserta didik ketika mereka sulit beradaptasi dan tidak mendapatkan dukungan dari keluarga maupun lingkungan sekitar. Seperti halnya; Siswa SMP Tewas Gantung Diri di Tarakan, Sempat Keluhkan Banyak Tugas Sekolah (Inews, 28 Oktober 2020, Republika 28 Oktober 2020). Seorang siswi SMA berinisial MI (16), di Kecamatan Manuju, Kabupaten Gowa, Sulawesi Selatan, ditemukan tewas terbujur kaku di bawah tempat tidurnya pada Sabtu (17/10/2020). Korban tewas diduga karena bunuh diri dengan cara minum racun rumput. Alasannya, karena depresi dengan banyaknya tugas sekolah yang dilakukan secara daring. (Kompas, 18 Oktober 2020, Liputan 6, 21 Oktober 2020). Kutipan-kutipan kasus tersebut telah menggambarkan betapa sangat berdampaknya kondisi pembelajaran jarak jauh pada mental peserta didik.

Secara psikologis peserta didik merupakan anak-anak yang pada taraf tertentu belum mempunyai bentukan mental emosional yang kokoh, sementara pada saat yang sama mereka harus bergelut dengan tekanan tugas pembelajaran daring, tekanan dari orang tua dan tekanan dari lingkungan sekitar termasuk hanlnya sarana dan prasarana yang mendukung mereka dalam mengerjakan tugas pembelajaran daring. Oleh sebab itu secara psikologis, anak peserta didik sangat rentan mengalami stress, kecemasan, dan depresi.

Stress secara khsuus megacu pada keadaan internal (individu) yang disebabkan karena adanya sesuatu yang secara fisik berpengaruh pada tubuh (penyakit, perubahan temperature, perubahan kondisi keluarga, lingkungan dan sebagainya) atau oleh lingkungan dan situasi sosial yang di nilai mengancam atau membahayakan. Hal-hal yang menimbulkan stress disebut dengan stessor, dimana stessor-stressor yang ada akan memicu terjadinya kecemasan dan depresi, yang dampak lebih jauh lagi akan mengarahkan perilaku akan pada sikap-sikap negative dan melanggar norma. Beberap bentuk dari akibat stress peserta didik akan mudah berperilaku antisosial: mencuri, merampas, dan bunuh diri.

Sedangkan Play therapy digunakan untuk memunculkan kekuatan terapeutik dari bermain yang digunakan untuk menolong konseli mencegah dan memecahkan masalah dan mencapai perkembangan yang optimal. Play Therapy digunakan sebagai alat diagnosis dan penyembuhan. Sedangkan menggambaar sebagai wujud dari art expresiion merupakan salah satu bentuk permainan yang dapat digunakan untuk mengenali simbol non verbal dan metafora yang dikomuniksikan dengan proses kreatif, yang mungkin sukar diekspresikan dengan kata-kata atau dengan modalitas lainnya (Lobby Loekmono, 2012). Therapy ini selain dapat mengungkap stressor anak, tindakan melukis itu sendiri dapat bersifat menyembuhkan karena memulai proses menguasai suatu kejadian dan keadaan sehingga membuat anak lebih berdaya, sehingga harapannya guru bimbingan konseling dapat membantu peserta didik yang mengalam stress untuk mengurangi bahkan mengatasi stressnya.

Berdasarkan latar belakang diatas, maka penulis mengajukan artikel program intervensi pada peserta didik dengan menggunakan Play Therapy Art Expression Menggunakan Media Menggambar Untuk Mengurangi Stress Peserta didik Dalam Mengerjakan Tugas Pembelajaran Daring. Harapannya dengan progam intervensi ini dapat digunakan untuk membantu anak-peserta didik khususnya, terkait permasalahan dan stress yang dialami.

\section{KAJIAN TEORI \\ Peserta didik}

Siswa atau yang disebut dengan peserta didik adalah bagian dari komponen pendidikan yang tidak bisa ditinggalkan, karena tanpa adanya kehadiran peserta didik tidak akan mungkin proses pembelajaran dapat berjalan. Peserta didik merupakan komponen utama, manusiawi yang menempati posisi sentral dalam proses belajarmengajar. Didalam proses kegiatan belajamengajar, peserta didik merupakan subjek pembelajaran yang ingin meraih cita-cita, memiliki tujuan dan harapam kemudian ingin mencapainya secara optimal. Menurut Undang-Undang No. 20 Tahun 2003 peserta didik adalah anggota masyarakat yang berusaha mengembangkan potensi diri melalui proses pembelajaran yang tersedia pada jalur, jenjang, dan jenis pendidikan tertentu.

Menurut Sudarwan Danim (2010: 1) "Peserta didik merupakan sumber utama dan terpenting dalam proses pendidikan formal". Peserta didik bisa belajar tanpa guru. Sebaliknya, guru tidak bisa mengajar tanpa adanya peserta didik. Oleh sebab itu kehadiran peserta didik menjadi keniscayaan dalam proses pendidikan formal atau pendidikan yang dilembagakan yang dimaksud dalah hal ini yakni sekolahan yang menuntut interaksi antara pendidik dan peserta didik.

\section{a. Karakteristik Peserta didik}

Setiap peserta didik memiliki karakteristik yang unik yang dihasilkan oleh lingkungan sekitar, pembelajaran dapat mencapai hasil yang diinginkan 
ketika guru/pembimbing mampu memahami karakteristik peserta didiknya. Karakteristik bawaan merupakan ayng dimiliki sejak lahir seperti halnya, kondisi fisik, kondisi kemampuan IQ, dll. Mengutip pendapat Tirtaraharja, (2000) mengemukakan 4 karakteristik peserta didik antara lain:

1. Individu yang memiliki potensi fisik dan psikis yang khas sehingga menjadikan makhluk yang unik

2. Individu yang sedang berkembang, anak mengalami perubahan dalam dirinya secara wajar

3. Individu yang membutuhkan bimbingan, dalam hal ini guru bimbingan dan konseling/konselor berperan aktif dalam membimbing, mendampingi dan mengarahkan peserta didik untuk mencapai perkembangan dan kemandirian yang optimal

Dari karakteristik peserta didik tersebut dapat diketuhui masa-masa perkembangan peserta didik yang btuh bimbingan dan pendampingan termasuk ketika peserta didik yang mengalami kesulitan dalam mengerjakan tugas pembelajaran daring akan sulit berdiskusi dengan teman sebab ketika mereka komunikasi belum tentu terbalas ole temannya, bertanya kepada sauadara, orang tua pastinya tidak selelu merespon dengan baik sebab semua pasti memiliki kesibukan sendiri, berbeda ketika peserta didik berada dikelas ketika mengalami kesulitas ada banyak teman yang bisa di ajak diskusi, bahkan bisa saling mencocokkan jawaban. Hal itulah yang mengakibatkan tingkat tekanan atau stress peserta didik dalam mengerjakan tugas di pembelajaran daring lebih tinggi dari pada pembelajaran tatap muka.

Clifford T. Morgan, dkk., 1986, dalam Tanti (2007) berpendapat bahwa terminology stress megacu pada keadaan internal (individu) yang disebabkan karena adanya sesuatu yang secara fisik berpengaruh pada tubuh (penyakit, perubahan keadaan, lingkungan dsb) atau oleh lingkungan dan situasi sosial yang di nilai mengancam atau membahayakan. Keadaan fisik, lingkungan sosial dan situasi sosial yang mengakibatkan stress di sebut stressor. Stressor tertentu mengakibatkan keadaan stress kemudian mengarahkan pada munculnya respon-respon tertentu baik berupa respon fisik pada tubuh (sakit perut, pusing, jantung berdebar, dan sebagainya), atau respon psikologis seperti kecemasan dan depresi.

Sedangkan yang terkait beberapa masalah yang sering dijumpai dan menjadi stessor oleh peserta didik dalam pemeblajaran daring anatara lain: a) tugas yang menumpuk dan memiliki deadline yang sama dengan karakteristik guru yang berbeda, b) tidak adanya dukungan keluarga (orang tua, saudara) yang membantu atau mengajarkan perihal tersebut, c) adanya tekanan dari guru mata pelajaran akan penyelesian tugas tersebut (ancaman nilai yang rendah/tidak naik kelas dsb) sehingga menjadi beban pikiran tersendiri pada benak peserta didik, d) adanya tekanan keluarga (orang tua, saudara, dsb) berkiatan dengan tugas sekolah dengan tugas yang lainnya, contoh membersihkan rumah, mencuci pakaian dll. e). kurangnya komunikasi dengan teman, sahabat maupun guru bimbingn dan konseling akan setiap masalah peserta didik alami, sehingga tidak memunculkan solusi akan masalah dari peserta didik tersebut

\section{b. Play Therapy Art Expression (Terapi Bermain Ekspresi Seni)}

Bila dicermati, pendekatan strategi play therapy (terapi bermain), tampaknya lebih menyentuh dengan aspek-aspek perkembangan pada peserta didik dan sesuai dengan karakteristik anak, hubungan sosial peserta didik yang cenderung tidak menyukai suatu yang serius. Terapi harus ada selingan bermain, sebagai salah satu intervensi kesehatan mental, dirancang untuk membantu anakanak tumbuh gembira dalam dunianya sesuai tugas perkembangannya. Untuk itu, konseling dengan pendekatan bermain menjadi suatu strategi pendekatan yang layak untuk diaplikasikan dalam situasi pendemi Covid-19 saat ini dengan tujuan membantu peserta didik yang mengalami stres dengan alasan, pertama, masa anak adalah masa bermain. Dengan meberikan konseling dengan cara bermain, berarti telah menempatkan anak dalam habitatnya (tidak serta-merta selalu mengerjakan tugas sekolah maupun tugas rumah dengan deadline tertentu). Kedua, kecenderungan anak belum seluruhnya mampu mengungkapkan maupun menyampaikan perasaan, ketakutan, kecemasan, dan kegelisahannya melalui bahasa verbal. Maka, melaui terapi bermain, segala bentuk ekspresi perasaan anak yang ditekan akan terungkap. Dan yang ketiga, masa anak disebut juga masa operasional konkret. Dengan media permainan, anak akan lebih leluasa mengungkapkan suasana perasaanya melalui benda atau alat-alat permainan yang konkret. Dengan demikian, suasana konseling dapat terbangun dengan hangat, antara konselor dengan anak (klien).

Goleman (2001) menjelaskan bahwa sekurang-kurangnya ada dua penyembuhan sekaligus yang dapat terjadi dalam proses permainan. Pertama, ingatan (traumatik) yang terwujud dalam bentuk permainan akan berada dalam konteks kecemasan tingkat rendah sehingga dapat mengumpulkan ingatan tentang trauma. Kedua, dalam permainan, anak-anak dapat memegang kendali, ke mana arah akhir cerita akan dibawa. Oleh karena itu peserta didik merasa berada dalam posisi pihak yang menang dan mereka dapat mengendalikan keadaan serta menjadi lebih berdaya ketika dia dapat kepercayaan di rumah. Dengan demikian, berarti peserta didik telah memiliki kunci menuju penyembuhan dari stressnya.

Terapi bermain mampu menciptakan suatu hubungan yang harmonis dan dinamis antara guru bimbingan dan konseling/konselor dengan peserta 
didik (konseli). Dengan terapi ini, sangat memungkinkan tercipta suatu relasi yang aman bagi peserta didik untuk mengekspresikan dan melakukan eksplorasi ke dalam dirinya yang berupa pikiran, perasaan, pengalaman, dan tingkah lakunya.

Disebut terapi bermain karena dalam pelaksanaannya menggunakan alat-alat permainan. Setiap permainan memiliki makna simbolis yang dapat membantu guru bimbingan dan konseling/konselor untuk dapat mendeteksi sumbersumber permasalahan anak. Sukmanigrum (2001) menyebutkan, sekurangnya ada lima bentuk alat permainan. Pertama, alat permainan ekspresi seni, seperti: pensil, cat air, lilin, krayon. Kedua, alat permainan khayal, seperti: boneka, pedangpedangan, atau pistol-pistolan, Ketiga, alat bermain konstruksi seperti: balok susun, lego. Keempat, bentuk games, seperti: congklak, domino, ular tangga, kartu, dan yang kelima, alat permainan lempar, seperti: bola, dan papan dart.

Menurut Sukmanigrum (2001), terapi bermain berdampak positif bagi pertumbuhan kesehatan mental anak. Terapi bermain tidak hanya memfasilitasi peserta didik dalam mengungkapkan emosinya, tetapi juga membantu terapis (konselor) untuk mendeteksi apa yang menjadi sumber ketakutan. mereka. Ketakutan yang dibawa ke alam bawah sadar akan terbawa melalui jenis dan pilihan permainan yang mereka lakukan.

Salah satu teknik dalam terapi bermain yang dapat digunakan untuk membantu anak yang mengalami trauma akibat tekanan bayaknya tugas pembelajaran daring yakni dengan menggunakan teknik menggambar. Teknik ini berkembang karena adanya kecendrungan peserta didik belum mampu mengekspresikan diri, pikiran dan peresaan mereka secara tepat untuk disampaikan kepada orang lain dengan menggunakan kata-kata.

Mengambar dapat menjadi solusi bagi peserta didik dalam mengekspresikan pikiran dan perasaan baik yang positif maupun yang negatif tentang diri, orang tua, keluarga, dan tuntutan dari gurunya. Menurut Djiwandono (2005) gambar memberikan arti kepada konselor jika dihubungkan dengan anak-anak yang terluka, mengasingkan diri, kecewa, dan tidak dapat mengungkapkan pikiran dan perasaan mereka kepada orang dewasa. Guru bimbingan dan konseling dapat menangkap sekilas perasaan dan pikiran yang tidak disadari dalam gambar anak yang tidak dapat diobservasi dalam model terapeutik yang lain.

Gambar dapat memberikan kesempatan kepada anak untuk melakukan katarsis dengan membebaskan perasaan dan memecahkan konflik secara aman. Proses mengambar dan hasilnya sebagai cara untuk membebaskan konflik, gambar yang telah di bikin peserta didik tidak perlu mengandung nilai estetika namun yang lebih di tonjolkan yakni katarsissnya, yang membuat mereka lega., menyalurkan kembali melalui sublimasi, dan memecahkannya.

\section{PROSEDUR PELAKSANAAN}

\section{a. Penjelasan Umum}

Strategi pendekatan play therapy art expression, akan lebih menyentuh dengan aspekaspek perkembangan pada peserta didik yang sesuai dengan karakteristik hubungan sosial anak-peserta didik yang cenderung tidak menyukai suatu yang serius. Terapi ini dengan menggunakan media menggambar, sebagai salah satu intervensi kesehatan mental, dirancang untuk membantu anakanak tumbuh gembira dalam dunianya. Terapi ini menjadi suatu pendekatan yang layak untuk dipergunakan dalam rangka membantu anak mengungkap ekspresi stress, mereduksi serta mengeliminasi sumbersumber keteganggan, sehingga lambat laun akan berpengaruh kepada pemulihan mental peserta didik.

Gambar memberikan arti kepada guru bimbingan konseling/konselor jika dihubungkan dengan dinamika psikologis peserta didik yang beragam, misalnya anak yang terluka hatinya, mengasingkan diri, kecewa, dan tidak dapat mengungkapkan pikiran dan perasaan mereka kepada orang dewasa. Konselor dapat menangkap sekilas perasaan dan pikiran yang tidak disadari dalam gambar anak yang tidak dapat diobservasi dalam model terapeutik yang lain. Selain itu gambar dapat memberikan kesempatan kepada anak untuk melakukan katarsis dengan membebaskan perasaan, stressor, dan memecahkan konflik secara aman.

Prinsip-prinsip dalam terapi bermain sebagaimana dijelaskan oleh Axline (dalam Christiana, 2008) adalah sebagai berikut : (1) Terapis harus menciptakan suasana yang hangat, hubungan yang bersahabat dengan anak; (2) Terapis menerima anak sebagaimana adanya; (3) Terapis harus mengembangkan perasaan permisif dalam hubungan anak; (4) Terapis harus waspada terhadap perasaan anak yang diekspresikan dan direfeksikan kembali dalam bentuk tingkah laku; (5) Terapis diharpkan mengahargai kemampuan anak dalam memcehkan masalahnya sendiri jika diberi kesempatan untuk melakukannya; (6) Terapis tidak diperkenankan langsung menegur perbuatan anak, atau intervensi nilai ; (7) Terapis jangan cepat-cepat melakukan terapi; (8) Terapis hanya mengembangkan keterbatasasn-keterbatasan yang diperlukan dalam menarik anak untuk terapi, dan pada kenyaatannya akan membuat anak sadar akan tanggung jawabnya dalam hubungan terapis.

\section{b. Tahap-Tahap Pelaksanaan}

Ada lima tahapan dalam proses bermain meliputi lima terapi R: Relating (Berhubungan), Releasing (Melegakan) perasaan, Re-Creating (menciptakan kembali) kejadian-kejadian 
pengalaman-pengalaman, hubungan-hubungan, Reexperience (Mengalami kembali) perasaan dan pikiran yang kacau dengan suatu cara yang memudahkan penegrtian baru, dan Resolving (Memecahkan) masalah dan konflik dengan mempraktikan tingkah laku baru dalam bermain.

\section{c. Contoh Aplikasi}

implementasi play teraphy art expression menggunakan media menggambar dibutuhkan alatalat dan bahan-bahan untuk menunjang penerapan terapi oleh guru bimbingan dan konseling/ konselor. Adapun bahan-bahan yang perlu disiapkan antara lain: alat tulis pensil, spidol warna dan buku gambar A3. Adapun contoh aplikasinya akan dijelaskan berdasarkan penjabaran dari tahap-tahap pelaksanaan Terapi Bermain:

1. Relating (berhubungan), dalam tahap ini konselor mencoba membina dan membangun hubungan komunikasi dengan peserta didik dengan baik, menciptakan hubungan yang dekat, hangat, nayaman, percaya, rileks, dan bebas berekspresi dengan tidak kaku dan canggung. Tahap awalan ini menjadi sangat pokok karena menjadi awal dibentuknya therapeutic alliance antara konselor dan konseli. Pada tahap ini pula guru bimbingan konseling dituntut lebih kreatif untuk membangun rapport yang baik, dapat dilakukan dengan perkenalan melalui gamegame ice breaking, menyampaikan maksud dan tujuan, dan mengenali kondisi dinamika hubungan untuk memberikan terapi.

2. Releasing (melegakan) perasaan. Dalam tahap ini guru bimbingan dan konseling/konselor melakukan penerimaan (acceptance) kepada konseli, memahami kondisi dengan empathic understanding, memberikan reassurance, serta menegaskan bahwa kehadirannya menerima dengan tengan terbuka apapun kondisi konseli.

3. Re-Creating (menciptakan kembali) kejadiankejadian pengalaman-pengalamann dalam tahap ini guru bimbingan dan konseling/konselor mencoba mengungkapkan kembali kejadian-kejadian dan pengalaman yang dialami konseli yang belum dapat terselesaikan (unfinishing business) seperti halnya beban tugas dari Guru A belum terseleseikan, ancaman dari kakak berkaitan tugas rumah, perintah orang tua yang belum diseleseikan dengan baik, terkadang pengalaman seperti itulah yang dialami peserta didik sebagai faktor pemicu stres. Oleh karena itu dalam tahap ini guru bimbingan konseling mencoba memunculkan kembali untuk menciptakan kesadaran peserta didik terkait stress yang dialaminya.

4. Reexperience (mengalami kembali) menumbuhkan perasaan dan pikiran yang kacau dengan suatu cara yang memudahkan pengertian baru. Setelah peserta didik memahami pengalaman dan hubunganhubungan yang menyebabkannya stress, peserta didik mulai merasakan kembali pengalaman-pengalaman stress yang ia alami. Pada tahap ini guru bimbingan konseling mengembangkan harapan-harapan baru, kebutuhan, serta pemahaman baru yang lebih positif dari diri konseli terkait pengalaman stess yang dialaminya sebelumnya.

5. Resolving (memecahkan) pemecahan masalah dan konflik dengan mempraktikan tingkah laku baru dalam bermain. Setelah konseli memahami pengalaman-pengalaman stressnya, serta mampu mengembangkan harapan dan pemahaman baru yang lebih positif, pada tahap ini konseli diminta mengekspresikan pengalaman, stress, masalah, dan juga harapan-harapannya ke dalam media (Buku Gambar/Kain kanvas) yang telah disediakan dengan cara menggambar atau mengoret-oret yang menjadikannya bahan katarsis.

\section{d. Evaluasi dan Tindak Lanjut}

Metode ini, merupakan bentuk bantuan sehingga evaluasi yang dilakukan ketika proses terapi berlangsung dan melalui hasil/gambar yang dibuat oleh peserta didik. Ketika proses berlangsung guru bimbngan konseling wajib belajar memahami dinamika psikologis peserta didik yang ditujukan baik secara verbal maupun non verbal. Sedangkan tahap evaluasi hasil dilakukan dengan mengintrepetasi makna, pesan dan kesan yang tertera dalam gambar peserta didik tersebut, jika diperlukan guru bimbingan konseling dapat pula meminta anak menceritakan dan menjelaskan apa maksud dan arti goresan / gambaran yang telah dibuatnya. Gambar atau coretan yang dibuat peserta didik akan memiliki beberapa pemaknaan, antara lain bermakna positif dan negatif, disamping bisa bermakna lain terkait dinamika psikologis peserta didik dalam pandemic Covid-19 saat ini.

Sedangkan sebagai tindak lanjut dalam terapi ini adalah dengan melihat hasil evaluasi, apabila dirasa dalam proses terapai ini ditemukan pengalaman-pengalaman atau stressor yang masih belum terselesikan maupun belum ditemukan solusi sendiri oleh peserta didik, maka dapat dilanjutkan dengan melakukan pelayanan konseling secara individual tatap muka untuk lebih mengintenskan terapi bantuan dan pencegahan hal-hal yang diluar kendali.

\section{SIMPULAN}

Strategi pendekatan play therapy art expression menggunakan media menggambar, dapat digunakan sebagai salah satu intervensi dalam membantu untuk mengurangi stress peserta didik dalam mengerjakan tugas pembelajaran daring. Strategi pendekatan ini menjadi suatu pendekatan 
yang layak untuk dipergunakan dalam rangka membantu peserta didik mengungkap ekspresi stress, mereduksi serta mengeliminasi sumbersumber keteganggan, sehingga lambat laun akan berpengaruh kepada pemulihan mental peserta didik terutama pada masa pandemic Covid-19 saat ini. Dalam strategi pendekatan ini pula guru bimbingan konseling/konselor membantu peserta didik untuk menemukan pikiran dan perasaan yang terdalam melalui karya seni walau tanpa melihat estetika yang penting bermakna, dan membantu mereka untuk memperoleh insight dan pertimbangan baru, sehingga berkembang lebih baik pemahaman dari diri sendiri dan berkomunikasi dengan orang-orang disekitarnya.

Lima tahapan dalam proses bermain meliputi lima terapi R atanara lain; Relating (Berhubungan), Releasing (Melegakan) perasaan, Re-Creating (menciptakan kembali) kejadian-kejadian pengalaman-pengalaman, hubungan-hubungan, Reexperience (Mengalami kembali) perasaan dan pikiran yang kacau dengan suatu cara yang memudahkan pemahaman baru, dan Resolving (Memecahkan) masalah dan konflik dengan mempraktikan tingkah laku baru dalam bermain. Semoga strategi pendekatan play therapy art expression mampu menjadi rujukan strategi guru bimbingan konseling dalam membantu peserta didiknya yang mengalami kecemasan maupun stress dalam mengerjakan tugas pembelajaran daring di masa pandemic Covid-19 ini.

\section{DAFTAR PUSTAKA}

Christiana, Elisabeth. 2008. Teknik Terapi Bermain pada Anak Usia Sekolah. Jurnal Pendidikan Dasar Universitas Negeri Surabaya.

Criatina, Maria. 2020. Siswa SMP Tewas Gantung Diri di Tarakan, Sempat Keluhkan Banyak Tugas Sekolah. Available at: https://regional.inews.id/berita. (accessed 2020/10/28)

Djiwandono, Sri Esti. W. 2005. Konseling dan Terapi dengan Anak dan Orang Tua. Jakarta: PT Gramedia Widiasarana Indonesia.

Goleman, D. 2000. Emotional Intelligence. Jakarta : PT Gramedia Pustaka Utama.

Jhon, Dewey. 2020. Pengertian Peserta Didik. Available at: https://www.silabus.web.id/pengertianpeserta-didik (accessed 2020/10/28)

Mashabi, Sania. 2020. Siswi Bunuh Diri diduga Depresi Karena Tugas Sekolah Daring. Available at: https://nasional.kompas.com/read/2020/1 $\underline{0 / 23 / 15110441}$. (accessed 2020/10/28)
Makdori, Yoppi. 2020. Siswa Bunuh Diri Karena Tugas Daring Belajar Jarak Jauh.

Available at: https://www.liputan6.com/news/read/43 88386/. (accessed 2020/10/28)

Prambadi, Akbar, Gilang: 2020. Sempat keluhkan tugas sekolah siswa di tarakan bunuh diri. Available at https://republika.co.id/berita/qivw7k456/ . (accessed 2020/10/28)

Santrock, J.W. 1999. Life Span Development. New York: Mc Graw Hill (Edisi Terjemahan Bahasa Indonesia).

Shalahudin, Odi. 2000. Peserta didik (Studi Kasus atas Persoalan Sosial). Available at http://odishalahuddin.wordpress.com [accessed 2011/11/23]

Sujanto, Agus. 1980. Psikologi Perkembangan. Jakarta: Aksara Baru.

Sukmaningrum, E. 2001. Terapi Bermain Sebagai Salah Satu Alternativ Penanganan Pasca Trauma Pada Anak. Jurnal Psikologi. Fakultas Psikologi Unpad. 